\title{
Evaluation of anti-diabetic activty of ethanolic and methanolic extracts of leaves of curcuma inodora against streptozotocin induced diabetic rats
}

\author{
Sabbani.Vidya ${ }^{1}$, A.Ramesh $^{2}$, S.Shobharani ${ }^{3}$ \\ ${ }^{l}$ Department of Pharmacology, Sitha Institute of Pharmaceutical Sciences, Bachupally, Hyderabad. Telangana \\ ,India \\ ${ }^{2}$ Department of Pharmacology, Vishnu Institute of Pharmaceutical Education \& Research, Medak. Telangana \\ ,India \\ ${ }^{3}$ Department of Pharmaceutical Chemistry, IST, CPS, JNTUH, Hyderabad. Telangana ,India
}

\begin{abstract}
The present research was focused to evaluate the antidiabetic activity of ethanolic and methanolic leaf extractsof Curcuma inodora in streptozotocin -induced diabetic rats. Ethanolic and methanolic leaves extract of Curcuma inodora $(100,200,400 \mathrm{mg} / \mathrm{kg})$ were administered to streptozotocin -induced diabetic rats for 14 day and blood glucose levels were estimated daily at regular intervals up to 14 days through out the treatment using Glucose peroxidation method. Treatment of streptozotocin induced diabetic rats with ethanolic leaf extract of Curcuma inodora caused a significant decrease in blood glucose levels at a dose of $200 \mathrm{mg} / \mathrm{kg}$ and $400 \mathrm{mg} / \mathrm{kg}$ when compared with standard glibenclamide drug. Treatment of streptozotocin induced diabetic rats with Methanolic leaf extracts of Curcuma inodora caused less significant decrease in blood glucose levels at a dose of 200 \& $400 \mathrm{mg} / \mathrm{kg}$ when compared with standard glibenclamide drug .The maximum reduction in the blood glucose was observed 6th hour to 10th hour after oral administration of 200 and $400 \mathrm{mg} / \mathrm{kg} \mathrm{b.w}$ of ethanolic extracts of leaves of curcum a inodora. These results suggest that ethanolic leaf extract of cururma inodora reduced elevated blood glucose levels more significantly compared to methanolic leaf extract in streptozotocin induced diabetic rats in a dose dependent manner.
\end{abstract}

\section{Introduction:}

Carbohydrates, fat and protein. It results from shortage or lack of insulin secretion or reduced sensitivity of the tissue to insulin[1]. Diabetes mellitus is the sixth leading cause of death globally [2]. Several drugs have been used in the management of the disease. These drugs have side effects and thus searching for a new class of compounds is essential to overcome diabetic problems [3]. Traditionally, a number of plants have been used in various herbal preparations in the management of diabetes and only a few of them have been proven scientifically [4]. More than 800 plants have been studied for their ant diabetic potentials [5] . Curcuma inodora is an attractive plant with large, showy flowers; scentless turmeric is also cultivated as an ornamental and used in traditional medicine for the treatment of muscular pain. Tubers are mixed with water to form a paste, which is applied locally. It is also used in the treatment of psychosomatic disorders and constipation[612].

\section{Collection of Plant Material}

\section{Materials and Methods}

The plant, Curcuma inodora, was collected from narsapur forest in narsapur,Medak district in the month of September.The plant was authenticated by Dr.Madhana Shetty, Department of Botany, Sri Venkateshwara University, Tirupathi .

\section{Preparation of extraction [13]}

The plant material first washed with water thoroughly to remove dirt and soil deposits and dried under shade until complete removal of moisture content,such dried plants were powdered by mechanically and passed through sieve no $80.500 \mathrm{gm}$ of powdered extract with $300 \mathrm{ml}$ of $90 \%$ ethanol solvent heated to $60-70^{\circ} \mathrm{C}$ by using soxhlet apparatus for 48 hours. The extract thus obtained was concentrated with the help of rotator vacuum evaporator and stored in $-2^{\circ} \mathrm{C}$ and different dose levels of plant extracts were prepared in $1 \%$ gum acacia solution and were used for studies.

\section{Animals}

Wistar albino rats of either sex (150-200 g) were maintained under controlled conditions for all sets of experiments.The rats were allowed to take standard laboratoryfeed and water ad libitum. 
The experimental protocol was approved by the institutional animal ethics committee of Vishnu institute of pharmaceutical sciencves,Narsapur,Medak , which wasregistered with Committee for the purpose of control and supervision of experiments on animal(CPCSEA), Govt. of India

\section{Acute Toxicity Studies [14,15]}

Determination of acute toxicity (LD50) The oral acute toxicity of alcoholic and Methanolic extracts were determined in albino Wistar albino rats (150-250 g), maintained under standard husbandry conditions. The animals were fasted 3 hrs prior to the experiment and "Up and Down" procedure of OECD Guidelines No. 425 method of CPCSEA was adopted for toxicity studies. Animals were administered with single doses of alcoholic and aqueous extracts in different groups and observed for the mortality during $48 \mathrm{hrs}$ study period (short term) toxicity. Based on the short term profile the doses for the next group of animals were determined as per OECD Guidelines No. 425. All the animals were observed for long term toxicity (14 days) and from the observed LD50 doses of, alcoholic and methanolic extracts 1/10th $\& 1 / 5^{\text {th }}$ doses were selected for the present study. The animals were also closely examined for signs of intoxication, lethargy, behavioral modification and morbidity.

\section{Induction of Diabetes[16-18]}

Diabetes was induced by a single intra-peritoneal dose of $60 \mathrm{mg} / \mathrm{kg}$ of $\mathrm{b}$. w of streptozotocin (STZ)dissolved in $0.1 \mathrm{M}$ fresh cold citrate buffer ( $\mathrm{pH} 4.5$ ) into $12 \mathrm{hr}$ fasted rats. The blood sampleswere taken on third day from retro orbital plexusof the rats for the estimation of blood glucose levels by using the auto analyzer. Rats withdiabetes having hyperglycemia (i.e. with bloodglucose of 185 to $360 \mathrm{mg} / \mathrm{dl}$ ) were taken for the experiment .

Evaluation of anti-diabetic activity of the ethanolic and methanolic leaf extracts of curcuma inodora[19]. The Diabetic animals were randomly divided into eight groups with 5 rats in each group and treated as follows for 14 days continuously orally.

Group I : Control group: $5 \mathrm{ml}$ of Gum acacia suspension.

Group II : Ethanolic leaf extract of Curcuma inodora ( ECI) $(100 \mathrm{mg} / \mathrm{kg} / \mathrm{day})$.

Group III : Ethanolic leaf extract of Curcuma inodora ( ECI) $(200 \mathrm{mg} / \mathrm{kg} / \mathrm{day})$

Group-IV : Ethanolic leaf extract of Curcuma inodora (ECI) (400 mg/kg/day)

Group V : Methanolic leaf extract of Curcuma inodora (MCI) (100 mg/kg/day).

Group VI : Methanolic leaf extract of Curcuma inodora (MCI) (200 mg/kg/day).

Group VII : Methanolic leaf extract of Curcuma inodora (MCI) (400 mg/kg/day).

Group VIII : Glibenclamide ( $10 \mathrm{mg} / \mathrm{kg})$

The fasting Blood Glucose Levels of all the rats were recorded at regular intervals during the experimental period. For acute study, the Blood Glucose Levels were monitored after 2, 4, 6 and $8,12 \mathrm{~h}$ of administration of a single dose and at the end of 1,3,5,7 and 14 days for prolonged treatments.

\section{Collection of Blood Samples and Serum Glucose Estimation[20-22]}

The blood samples $(0.5 \mathrm{ml})$ were collected for every time intervals of $0,2,4,8,12$, hr in $1 \mathrm{ml}$ Eppendorf's tubes. Serum was separated by centrifuging at $3000 \mathrm{rpm}$ for 10 minutes. $30 \mu \mathrm{l}$ of serum sample and $3 \mathrm{ml}$ of working glucose reagent were taken in to a dry and clean test tube and incubated for 10 minutes at 37o C. The pink color developed was measured by using auto analyzer.

\section{Statistical Analysis}

The values were expressed as mean \pm SEM. The data was subjected to the analysis of variance(one way ANOVA) to determine the significanceof changes followed by students "t"-test[23-25].The statistical significance of difference between two independent groups were calculated for the determination of blood glucose levels.

\section{Results}

The extracts did not produce any toxic signs during the observation period for 24 hours in any of the rats they were tested. Hence it was concluded that the extracts are safe upto $2000 \mathrm{mg} / \mathrm{kg}$. The mean blood glucose levels of control and drug treated animals after oral administration of different extracts at different doses $(100,200$ and $400 \mathrm{mg} / \mathrm{kg} \mathrm{b.w})$ of Curcuma inodora leaves at various time intervals $(0,2,4,8,12$, hrs $)$ are shown in Table 1 and Figure 1.

The statistical significance of decrease in blood glucose levels was calculated with respect to initial blood glucose levels. Oral administrationof $1 \%$ gum acacia suspension did not change the blood glucose levels 
of rats. The blood glucose levels of diabetic rats treated with Glibenclamide $(10 \mathrm{mg} / \mathrm{kg}$ b.w) showed significant $(\mathrm{P}<0.001)$ decrease in blood glucose levels at $6-12^{\text {th }}$ hrs, more significantly. Nevertheless, the reduction in mean blood glucose levels was less significant at $12 \mathrm{hrs}$.

The ethanolic leaf extract of Curcuma inodora at a dose of $100 \mathrm{mg} / \mathrm{kg} \mathrm{b}$. w ,showed less significant $(\mathrm{P}<0.05)$ decrease in blood glucose levels at 6 th $\mathrm{hr}$ and more significant $(\mathrm{P}<0.01)$ decrease in blood glucose level at 8th hr. However,oral administration of $200 \mathrm{mg} / \mathrm{kg} \& 400 \mathrm{mg} / \mathrm{kg} \mathrm{b}$. w of leaves of Curcuma inodora showed less significant $(\mathrm{P}<0.05)$ decrease in blood glucose levels at $4^{\text {th }}$ hour more significant $(\mathrm{P}<0.01)$ decrease in blood glucose levels at $6^{\text {th }} \mathrm{hr}$ and highly significant $(\mathrm{P}<0.001)$ decrease in blood glucose levels at $8^{\text {th }}$ hr.

The Methanolic extract of leaves of Curcuma inodora a dose of $100,200 \& 400 \mathrm{mg} / \mathrm{kg} \mathrm{b}$. w, showed less significant $(\mathrm{P}<0.05)$ decrease in blood glucose levels.

The decrease in blood glucose levels produced by the oral administration of different doses (100, 200 and $400 \mathrm{mg} / \mathrm{kg}$ b.w) at various time intervals for 14 days shown in Table 2 and Figure 1.

\section{Discussion}

The data obtained from the test carried out on STZ diabetic rats clearly showed that the ethanolic extracts of Curcuma inodora leaves at dose levels of 100,200 and $400 \mathrm{mg} / \mathrm{kg}$ b.w produced a significant reduction of blood glucose level than methanolic extracts. Comparing the results of 100,200 and $400 \mathrm{mg} / \mathrm{kg} \mathrm{b}$. w ethanolic extracts of Curcuma inodora leaves in diabetic rats, it was found that the ethanolic extract at $400 \mathrm{mg} / \mathrm{kg}$ b.w showed highly significant $(\mathrm{P}<0.001)$ decrease in blood glucose levels when compared to control STZ induced diabetic animals which was comparable with the standard glibenclamide $(10 \mathrm{mg} / \mathrm{kg} \mathrm{b} . \mathrm{w})$. The lowest blood glucose levels were observed at $6^{\text {th }}$ and 8 th hrs after oral administration of ethanolic leaf extracts of curcuma inodora the reduction of blood glucose levels in diabetic rats was in a dose dependent manner compared to glibenclamide which is used in treatment of Type II diabetes mellitus. The standard drug Glibenclamide stimulates insulin secretion form beta cells of islets of langerhans. From the study, it is suggested that the possible mechanism by which the plant extracts decrease the blood glucose level may be by potentiation of insulin effect either by increase in pancreatic secretion of insulin form beta cells of Islets of langerhans. Histopathological studies of pancrease and kidney are under study. The bioactive principle will be identified and characterization will be done based on their chemical nature.

\section{References:}

[1]. Prasad SK, Kulshreshtha A, Qureshi TN. Antidiabetic activity of some herbal plants in streptozotocin-induced diabetic albinorats. Pak J Nutr 2009; 8(5): 551-557.

[2]. Nash D, Koenig J, Novielli K, Liberoni R, Reisman M. The importance of the individualized pharmaceutical therapy in the treatment of diabetes mellitus. Dis Manag 2001; 4(1): 5-23.

[3]. Noor A, Gunasekaran S, Manickam AS, Vijayalakshmi MA. Antidiabetic activity of Aloe vera and histology of organs in streptozotocininduced diabetic rats. Curr Sci 2008; 94: 1070-1076.

[4]. Jia Q, Liu X, Wu X, Wang R, Hu X, Li Y, et al. Hypoglycemic activity of a polyphenolic oligomer-rich extract of Cinnamomum parthenoxylon bark in normal and streptozotocin-induced diabetic rats. Phytomedicine 2009; 16(8): 744-750.

[5]. Daisy P, Eliza J. Hypoglycemic property of polyherbal formulation in streptozotocin induced diabetic rats. Biochem Cell Arch 2007; 7: 135-140.

[6]. Jagtap, S. D. et al. (2009). Traditional ethnomedicinal knowledge confined to the Pawra tribe of Satpura hills, Maharashtra, India. Ethnobotanical Leaflets 13: 98-115.

[7]. Leong-Škorničková, J., Š́́da, O. \& Marhold, K. (2010). Back to types! Towards stability of names in Indian Curcuma L. (Zingiberaceae). Taxon 59: 269-282.

[8]. Mangaly, J. K. \& Sabu, M. (1993). A taxonomic revision of the south Indian species of Curcuma. Rheeda 3: $139-171$.

[9]. Patil, H. M. \& Bhaskar, V. V. (2005). Medicinal uses of plants by tribal medicine men of Nandurbar district Maharashtra. Natural Product Radiance 5: 125-130.

[10]. Raju, V. S., Reddy, C. S. \& Ragan, A. (2006). Curcuma L. (Zingiberaceae) in Andhra Pradesh: a preliminary study. Journal of Economic and Taxonomic Botany 30: 773-775.

[11]. Reddy, S. et al. (2006). Ethnobotanical observations of some endemic plants of astern Ghats, India. Ethnobotanical Leaflets 10: 8291.

[12]. Rommand-Monnier, F. (2009). Curcuma inodora. Assessment using IUCN Categories and Criteria 3.1 (IUCN 2001). Royal Botanic Gardens, Kew. [SRLI conservation assessments, pending approval by IUCN.

[13]. Litchfield JT, Wilcoxon FA. Simplified method of evaluating dose effect xperiments. Journal of Pharmacology and Experimental Therapeutics 1949;96:99-133

[14]. Ghosh M.N.Fundamentals of Experimental Pharmacology.2nd Edn Scientific Book Agency,Calcutta, 1984, $178-210$.

[15]. Gonzalez M, Zarzuelo A, Gamez MJ, Utrilla MP,Jimenez J, Osuna I. Hypoglycemic activity of olive leaf. Planta Medica 1992; 58:513-515.]

[16]. Padmini-kedar, Chakrabharathi CH. Effect of bitter gourd(Momordica charantia) seed andglibenclamide in streptozotocin induceddiabetes mellitus. Indian J. Experimental1982;20:181-184

[17]. Regi Raphael K, Sabu MC, Ramadasan Kuttan.Hypoglycemic effect of methanol extract ofPhyllanthus amarus Schum \& Thonn on alloxaninduced diabetes mellitus in rats and itsrelation with antioxidant potential. Ind J. ExpBiol 2002;40: 905-909.

[18]. Khosla P, Gupta DD, Nagpal RK. Effect ofTrigonella foenum graecum (fenugreek) onblood glucose in normal and diabetic rats. Ind. J.Physiol. Pharmacol 1995;39:173-174. 
[19]. Antia BS, Okokon JE, Umoh EE, Udobang JA. Antidiabetic activity ethanolic leaf extract of Panicum maximum. Int J Drug DevRes 2010; 2(3): 488-492.

[20]. Philip D Mayne. Carbohydrate Metabolism in Clinical chemistry in Diagnosis and Treatment,ELBS; 1994.16.

[21]. Trinder P. Determination of Glucose in BloodUsing Glucose Oxidase with an AlternativeOxygen Acceptor. Ann. Clin. Biochem $1969 ; 6: 24-25$.

[22]. Raabo E, Terkildsen TC. On the enzymaticdetermination of blood glucose. Scand. J. Clin.Lab. Invest1960; 12:402-407.

[23]. Snedecor GW. Cochran WG: The comparison of two samples, in Statistical Methods, Iowa StateUniversity Press, Ames, Iowa, 1967, 91-119.

[24]. Woodson RF. Statistical methods for theanalysis of biomedical data series in probability and Mathematical statistics, wiley, New York, 1987,315.

[25]. Zar JH. Biostatistical Analysis, Prentice-Hall.Inc.,Englewood Chiffs. NJ, 1974,151.]

Table: 1 Antidiabetic effect of leaf extracts of Curcuma inodora on blood glucose level of streptozotocin -induced diabetic rats during acute study (mean \pm SEM) $(n=5)$.

\begin{tabular}{|c|c|c|c|c|c|c|c|c|c|c|c|}
\hline \multirow[t]{2}{*}{ Treatments } & \multirow[t]{2}{*}{ Dose $\mathrm{mg} / \mathrm{kg}$} & \multicolumn{10}{|c|}{ Blood glucose levels $(\mathrm{mg} / \mathrm{dL})$ in hours } \\
\hline & & Ohr & $2 \mathrm{hr}$ & & $4 \mathrm{hr}$ & & $6 \mathrm{hr}$ & & $8 \mathrm{hr}$ & & $12 \mathrm{hr}$ \\
\hline $\begin{array}{lll}\begin{array}{l}\text { Control( } \\
\text { acacia) }\end{array} & 1 \% \text { gum } \\
\end{array}$ & $5 \mathrm{ml}$ & $\begin{array}{ll}311 & \pm \\
0.123 & \\
\end{array}$ & $\begin{array}{l}324 \pm \\
3.87\end{array}$ & & $\begin{array}{l}318 \pm \\
2.89\end{array}$ & & $\begin{array}{l}312 \pm \\
6.67\end{array}$ & & $\begin{array}{l}305 \pm \\
2.14\end{array}$ & & $\begin{array}{l}321 \pm \\
3.54\end{array}$ \\
\hline ECI & 100 & $\begin{array}{l}298 \\
3.78\end{array}$ & $\begin{array}{l}231 \\
3.56\end{array}$ & & $\begin{array}{l}222 \\
4.34\end{array}$ & \pm & $\begin{array}{l}219 \\
1.98\end{array}$ & \pm & $197 \pm 0.45$ & & $\begin{array}{ll}174 & \pm \\
4.56 & \end{array}$ \\
\hline ECI & 200 & $342 \pm 1.45$ & $\begin{array}{l}289 \\
4.56\end{array}$ & & $\begin{array}{l}234 \\
1.34 \\
\end{array}$ & \pm & $\begin{array}{l}156 \\
6.34\end{array}$ & \pm & $\begin{array}{l}134 \\
1.45\end{array}$ & & $128 \pm 1.35$ \\
\hline ECI & 400 & $\begin{array}{l}312 \\
1.78\end{array}$ & $\begin{array}{l}301 \\
2.56\end{array}$ & & $\begin{array}{l}278 \\
1.45 * *\end{array}$ & \pm & $\begin{array}{l}127 \\
3.65 * *\end{array}$ & & $\begin{array}{l}129 \\
2.54 * *\end{array}$ & & $123+1.89$ \\
\hline MCI & 100 & $\begin{array}{l}334 \\
5.78\end{array}$ & $\begin{array}{l}321 \\
8.09\end{array}$ & & $\begin{array}{l}308 \\
2.98\end{array}$ & \pm & $\begin{array}{l}278 \\
3.89\end{array}$ & \pm & $\begin{array}{l}245 \\
4.67\end{array}$ & & $\begin{array}{l}281 \\
4.523\end{array}$ \\
\hline MCI & 200 & $\begin{array}{l}309 \\
3.78\end{array}$ & $\begin{array}{l}298 \\
1.09 \\
\end{array}$ & \pm & $\begin{array}{l}281 \\
2.09\end{array}$ & \pm & $\begin{array}{l}276 \\
2.90\end{array}$ & \pm & $\begin{array}{l}271 \\
2.90\end{array}$ & & $\begin{array}{l}272 \\
3.98\end{array}$ \\
\hline MCI & 400 & $298 \pm 6.78$ & $\begin{array}{l}289 \\
5.56\end{array}$ & & $\begin{array}{l}278 \\
1.23^{*}\end{array}$ & \pm & $\begin{array}{l}234 \pm \\
.65^{*}\end{array}$ & 1 & $\begin{array}{l}213 \\
2.54\end{array}$ & & $\begin{array}{l}219 \\
1.23\end{array}$ \\
\hline Glibenclamide & 10 & $\begin{array}{l}345 \\
2.56\end{array}$ & $\begin{array}{l}291 \\
3.45\end{array}$ & & $\begin{array}{l}147 \\
2.67 * *\end{array}$ & \pm & $\begin{array}{l}149 \\
3.67 * *\end{array}$ & 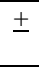 & $\begin{array}{l}142 \\
3.78 * *\end{array}$ & & $\begin{array}{l}159 \\
1.56\end{array}$ \\
\hline
\end{tabular}

Values are expressed as mean \pm SEM, $\mathrm{n}=5 ; \mathrm{n}=$ Number animals per treatment; ** Significantly different from Control, $\mathrm{p}<0.01$

Table: 2 Effect of leaf extracts of Curcuma inodora on blood glucose level of streptozotocin -induced diabetic rats during prolonged treatment

\begin{tabular}{|c|c|c|c|c|c|c|c|}
\hline \multirow[t]{2}{*}{ Treatments } & \multirow[t]{2}{*}{ Dose $\mathrm{mg} / \mathrm{kg}$} & \multicolumn{6}{|c|}{ Blood glucose levels $(\mathrm{mg} / \mathrm{dL})$ in days } \\
\hline & & Day0 & Day1 & Day3 & Day5 & Day7 & Day14 \\
\hline $\begin{array}{l}\text { Control( } 1 \% \text { gum } \\
\text { acacia) }\end{array}$ & $5 \mathrm{ml}$ & $\begin{array}{ll}301 & \pm \\
0.123 & \\
\end{array}$ & $\begin{array}{l}314 \pm \\
1.87\end{array}$ & $\begin{array}{r}318 \pm \\
4.98\end{array}$ & $\begin{array}{l}312 \pm \\
7.17\end{array}$ & $\begin{array}{l}305 \pm \\
1.11\end{array}$ & $\begin{array}{l}321 \pm \\
1.19\end{array}$ \\
\hline ECI & 100 & $\begin{array}{l}334 \\
3.78\end{array}$ & $\begin{array}{l}134 \\
3.56\end{array}$ & $145 \pm 4.34$ & $\begin{array}{l}121 \\
1.98\end{array}$ & $127 \pm 0.45$ & $\begin{array}{l}134 \\
4.56\end{array}$ \\
\hline ECI & 200 & $342 \pm 1.45$ & $\begin{array}{l}159 \\
4.56 \\
\end{array}$ & $\begin{array}{ll}134 & \pm \\
1.34 & \\
\end{array}$ & $\begin{array}{ll}156 & \pm \\
6.34 & \\
\end{array}$ & $\begin{array}{ll}134 & \pm \\
1.45 & \\
\end{array}$ & $128 \pm 1.35$ \\
\hline ECI & 400 & $\begin{array}{l}312 \\
1.78\end{array}$ & $\begin{array}{ll}127 & \pm \\
2.56 * * & \end{array}$ & $\begin{array}{ll}138 & \pm \\
1.45^{* *} & \end{array}$ & $\begin{array}{l}121 \\
3.65 * *\end{array}$ & $\begin{array}{l}129 \\
2.54 * *\end{array}$ & $\begin{array}{ll}129 & \pm \\
1.89 * * & \end{array}$ \\
\hline MCI & 100 & $\begin{array}{l}334 \\
5.78\end{array}$ & $\begin{array}{l}321 \\
8.09\end{array}$ & $\begin{array}{l}308 \\
2.98\end{array}$ & $\begin{array}{l}278 \\
3.89\end{array}$ & $\begin{array}{l}245 \\
4.67\end{array}$ & $\begin{array}{l}281 \\
4.523\end{array}$ \\
\hline MCI & 200 & $\begin{array}{l}309 \\
3.78\end{array}$ & $\begin{array}{l}298 \\
1.09\end{array}$ & $\begin{array}{l}281 \\
2.09\end{array}$ & $\begin{array}{l}276 \\
2.90\end{array}$ & $\begin{array}{l}271 \\
2.90\end{array}$ & $\begin{array}{l}272 \\
3.98\end{array}$ \\
\hline MCI & 400 & $298 \pm 6.78$ & $\begin{array}{l}289 \\
5.56 \\
\end{array}$ & $\begin{array}{l}278 \\
1.23 * \\
\end{array}$ & $\begin{array}{l}234 \pm \\
.65^{*} \\
\end{array}$ & $\begin{array}{l}213 \\
2.54 * \\
\end{array}$ & $\begin{array}{l}219 \\
1.23 * \\
\end{array}$ \\
\hline Glibenclamide & 10 & $\begin{array}{l}345 \\
2.56\end{array}$ & $\begin{array}{ll}122 & \pm \\
3.45 * * & \end{array}$ & $\begin{array}{ll}127 & \pm \\
2.67 * * & \\
\end{array}$ & $\begin{array}{ll}123 & \pm \\
3.67 * * & \\
\end{array}$ & $\begin{array}{ll}139 & \pm \\
3.78 * * & \end{array}$ & $\begin{array}{ll}131 & \pm \\
1.56 * * & \end{array}$ \\
\hline
\end{tabular}

Values are expressed as mean $\pm \mathrm{SEM}, \mathrm{n}=5 ; \mathrm{n}=$ Number animals per treatment;

** Significantly different from Control, $\mathrm{p}<0.01$ 


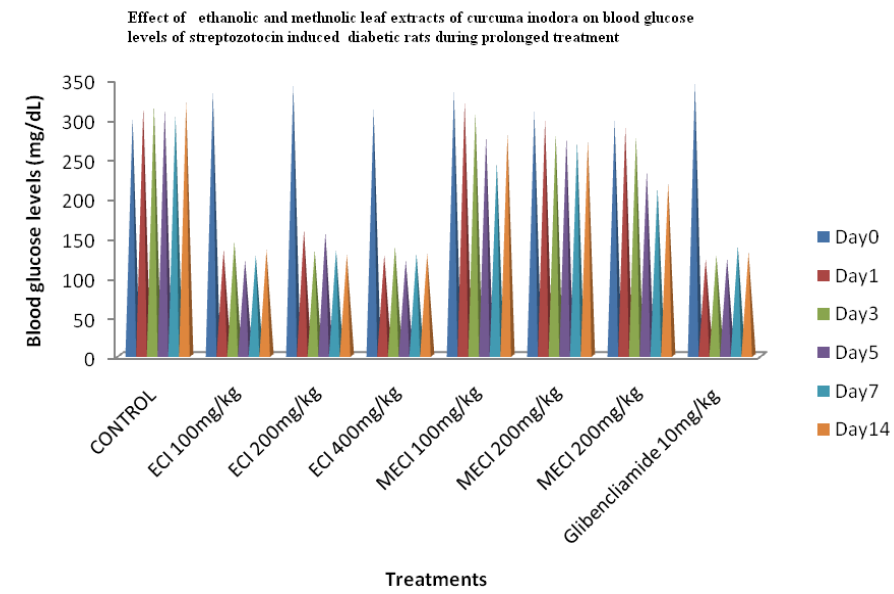

